\title{
Trends in the development of human stem cell-based non-animal drug testing models
}

\author{
Su-Jin Lee and Hyang-Ae Lee* \\ Department of Predictive Toxicology, Korea Institute of Toxicology, Korea Research Institute of Chemical Technology, Daejeon 34114, Korea
}

\section{ARTICLE INFO}

Received August 18, 2020

Revised August 31, 2020

Accepted August 31, 2020

\section{*Correspondence \\ Hyang-Ae Lee \\ E-mail: vanessa@kitox.re.kr}

\section{Key Words}

In vitro model

Non-clinical testing

Organ-on-a-chip

Organoid

Stem cell

\begin{abstract}
In vivo animal models are limited in their ability to mimic the extremely complex systems of the human body, and there is increasing disquiet about the ethics of animal research. Many authorities in different geographical areas are considering implementing a ban on animal testing, including testing for cosmetics and pharmaceuticals. Therefore, there is a need for research into systems that can replicate the responses of laboratory animals and simulate environments similar to the human body in a laboratory. An in vitro two-dimensional cell culture model is widely used, because such a system is relatively inexpensive, easy to implement, and can gather considerable amounts of reference data. However, these models lack a real physiological extracellular environment. Recent advances in stem cell biology, tissue engineering, and microfabrication techniques have facilitated the development of various $3 \mathrm{D}$ cell culture models. These include multicellular spheroids, organoids, and organs-on-chips, each of which has its own advantages and limitations. Organoids are organ-specific cell clusters created by aggregating cells derived from pluripotent, adult, and cancer stem cells. Patient-derived organoids can be used as models of human disease in a culture dish. Biomimetic organ chips are models that replicate the physiological and mechanical functions of human organs. Many organoids and organ-on-a-chips have been developed for drug screening and testing, so competition for patents between countries is also intensifying. We analyzed the scientific and technological trends underlying these cutting-edge models, which are developed for use as non-animal models for testing safety and efficacy at the nonclinical stages of drug development.
\end{abstract}

\section{INTRODUCTION}

The rapid progress of science and technology related to the drug development has resulted in numerous new drug candidates using new techniques. However, the number of new licensed products has been declining, despite the expenditure of large amounts of money on R\&D [1,2]. This decline is partly because the U.S. Food and Drug Administration (FDA)'s screening standards have been strengthened since 2000, but the technologies for assessment of safety and efficacy used in the development of new drug products take time to reflect the technological advances.
Experimental animals are useful models in pre-clinical tests, but the tests are time-consuming and costly. In addition, many pharmaceutical companies in various countries, including those developing chemicals and cosmetics, have recently banned animal testing due to ethical issues and errors in predictions due to differences between species $[3,4]$. Therefore, the need for the development of new non-animal test models is increasing.

With the recent rapid development of stem cell technology, many studies seeking to differentiate human stem cells into specific cells that make up organs and use them for nonclinical testing have been carried out around the world. In vitro two-dimen-

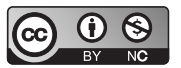

This is an Open Access article distributed under the terms of the Creative Commons Attribution Non-Commercial License, which permits unrestricted non-commercial use, distribution, and reproduction in any medium, provided the original work is properly cited. Copyright @ Korean J Physiol Pharmacol, pISSN 1226-4512, elSSN 2093-3827
Author contributions: Conceptualization, funding acquisition, project administration, writing-original draft, and review \& editing of manuscript: H.A.L. Data processing \& analysis, writing-original draft: S.J.L. 
sional cell culture models are used early in nonclinical testing, because they generate large amounts of basic data, which can be compared and analyzed, and are relatively inexpensive and easy to use $[5,6]$. However, there are limits to present a real physiological cell environment under the conditions of incubation in a static environment. Three-dimensional (3D) cell culture models, have been proposed as an ideal way to imitate the form and function of human organs, although such models are not yet complete [7]. Thus, there are increasing attempts to use in vitro models made using 3D culture methods for safety and efficacy testing of drug candidates $[8,9]$, and competition among countries for patents is getting fiercer. In this review, we survey the trends in development of human stem cell-derived 3D culture models, organoids, and organ-on-a-chip models, which are being developed as nonanimal models for use in drug development.

\section{DEVELOPMENT OF NON-CLINICAL TESTING MODELS USING ORGANOIDS}

Organoids (also known as organ-like organisms) are organspecific cell clusters created by aggregating cells separated from stem cells or organs in 3D culture. They are collections of cells with a 3D structure containing organ-specific cells. Organoids can self-organize; that is, they can be spatially organized in a form similar to the actual organ. They can reproduce organ-specific functions, and form systems. Depending on the cell type of origin, it is possible to distinguish between pluripotent stem cellderived organoids, adult stem cell-derived organoids, and cancer cell-derived organoids (Fig. 1).

\section{Pluripotent stem cell-derived organoids}

Many studies have been carried out into the production of organoids using 3D culture techniques with various growth factors and an extracellular matrix from embryonic and induced pluripotent stem cells.

As Lancaster and Knoblich [10] published in Science in 2014, there has been considerable research into the production of various organoids, including intestines, kidneys, and brains. The cellular signals related to the differentiation of each type of organoid have also been studied. For example, in the case of intestinal organoids, the pluripotent stem cells (PSCs) were treated with the proteins Wnt3a and Fgf4 and then cultured in a supporting scaffold (such as Matrigel), whereas in the case of kidney organoids, the PSCs were treated with the BMP4, Fgf9, and retinoic acid (RA) to generate kidney tissue [10-13].

In the journal Cell, in a paper published in 2006 [14], the signaling system related to differentiation into organoids in each organ has been investigated, and many studies have succeeded in producing organoids including intestines, liver, brain, kidneys, lungs, and pancreatic organoids. These organoids have been validated using gene expression analysis, protein expression analysis, and a functional analysis that can determine each organ-specific characteristic function. Proven organoids have been used in research to establish models of diseases such as cancer, cystic fibrosis, virus and bacterial infections. Also, the organoids are used to inducing mutations, profiling of transcripts, transplantation studies, CRISPR/Cas9 gene correction, and other studies [15-17]. Liver organoids have been used in Alagille syndrome and cystic fibrosisassociated liver disease modeling, and colon organoids have been used to model inflammatory bowel disease [18-21]. Pancreatic organoids have been used for cancer modeling, pulmonary organoids for cystic fibrosis, and brain organoids have been used in investigations into autism and microcephaly [22-28].

\section{Adult stem cell-derived organoids}

Adult stem cell-derived organoids are derived from organspecific stem cells present in each organ in the body. They have the ability to differentiate into the cells that form each organ [29]. Many studies have been conducted on various adult stem cell-derived organoids. There have been reports of systematic follow-up studies through the induction of tamoxifen in relation to tongue cancer, using tongue-stem cell-derived organoids, and many studies have been conducted into the establishment and utilization of intestinal organoids, using $\mathrm{Lgr}^{+}$stem cells $[11,30]$. Gastric tissuederived organoids are composed of $\mathrm{LgrF}^{+}$stem cells, mucous neck cells, pit cells, and enteroendocrine cells, and the corpus is composed of chief cells, neck mucus cells, and spring cells [31]. These

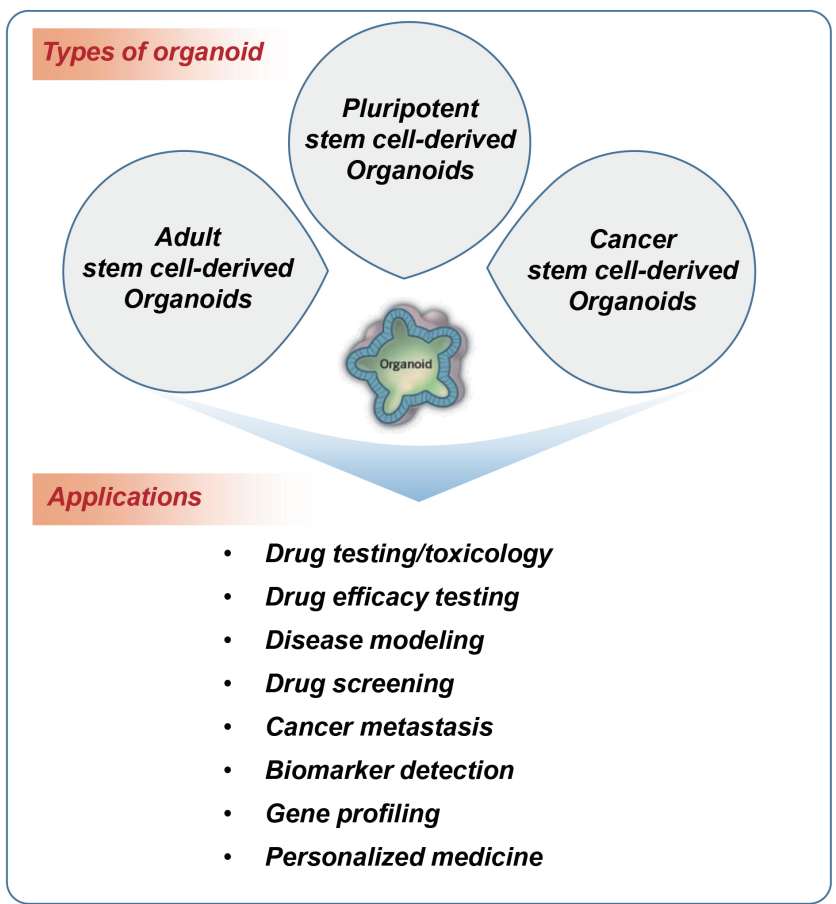

Fig. 1. Types of organoids depending on the originated cells and their applications. 
organoids are used in a variety of studies related to transcript profiling, mesenchymal cells, co-culture studies, infections by adenoviruses or retroviruses, and cancer modeling [31,32]. In addition, pancreatic organoids, prostate organoids, and small intestine organoids are used in cancer modeling [33-37]. The esophageal tissue-derived organoids are used in modeling of Barrett's esophagus [38]. Pluripotent stem-derived organoid and patient-derived disease organoids have been established for the development of therapeutic agents and the study of disease mechanism [39]. In Fig. 2, we summarize the established organoids for human diseases in liver [21,40-44], lung [45], brain [24,27,28,46-49], lingual [30], colon [38,50,51], intestine [33,37,52,53], ovary [54], retina [55], kidney [56,57], esophagus [58], heart [59], breast [60], stomach $[52,61]$, and pancreas $[26,62,63]$.

\section{Cancer cell-derived organoids}

Cancer cell-derived organoids are referred to as tumor organoids (tumoroids), and are made using a 3D culture method in vitro using tumor tissue obtained from animal models or cancer patients [64]. This type of organoid is expected to have a variety of characteristics that appear due to the tumor microenvironment and individual characteristics of cancer. Research into anti-cancer screening using tumor organoids is being actively carried out. Hans Clevers' research team at the Hubrecht Institute in Utrecht, the Netherlands, established 22 tumor organoid biosample banks from the tissues of 20 patients with colorectal cancer [65]. Using these organoids, 83 anti-cancer drugs are being examined to identify the specific genes that are upregulated in response to each drug. This high-efficiency drug screening is expected to be useful in the use of personalized precision medicine using patient-derived organoids [66,67]. The Calvin Kuo's group at Stanford produced models by introducing two to four cancer mutations in normal colon, gastrointestinal, and pancreatic organoids with tumor-like phenotypes. These models are expected to be valuable for finding new tumor-inducing mutants and verifying their function [68,69]. In the Republic of Korea, the Asan Medical Center and a joint research team are building a biobank of liver cancer, stomach cancer, colon cancer, lung cancer, and pancreatic cancer organoids (http://brc.amc.seoul.kr/).

\section{Global scientific trends in organoid research}

In order to investigate the trends in global organoid research, organoid-related publications were analyzed by Scopus, a leading journal search site (https://www.scopus.com/). We searched for nonclinical tests using organoids in the ten years from 2008 to 2019 , and found 195 documents. The rankings by year, country, and institution were investigated for the 195 documents searched. According to the number of papers released on a yearly basis, the use of nonclinical testing technology using organoids increased sharply between 2016 and 2019 (Fig. 3). The top 10 countries were the United States of America, followed by the United Kingdom, the Netherlands, Germany, Japan, China, Italy, Australia, Austria, and the Republic of Korea (Fig. 4). The top five institutions were the University Medical Center Utrecht, the Memorial Sloan-Kettering Cancer Center, Harvard Medical School, Hubrecht Laboratory KNAW Netherlands Institute for Developmental Biology,

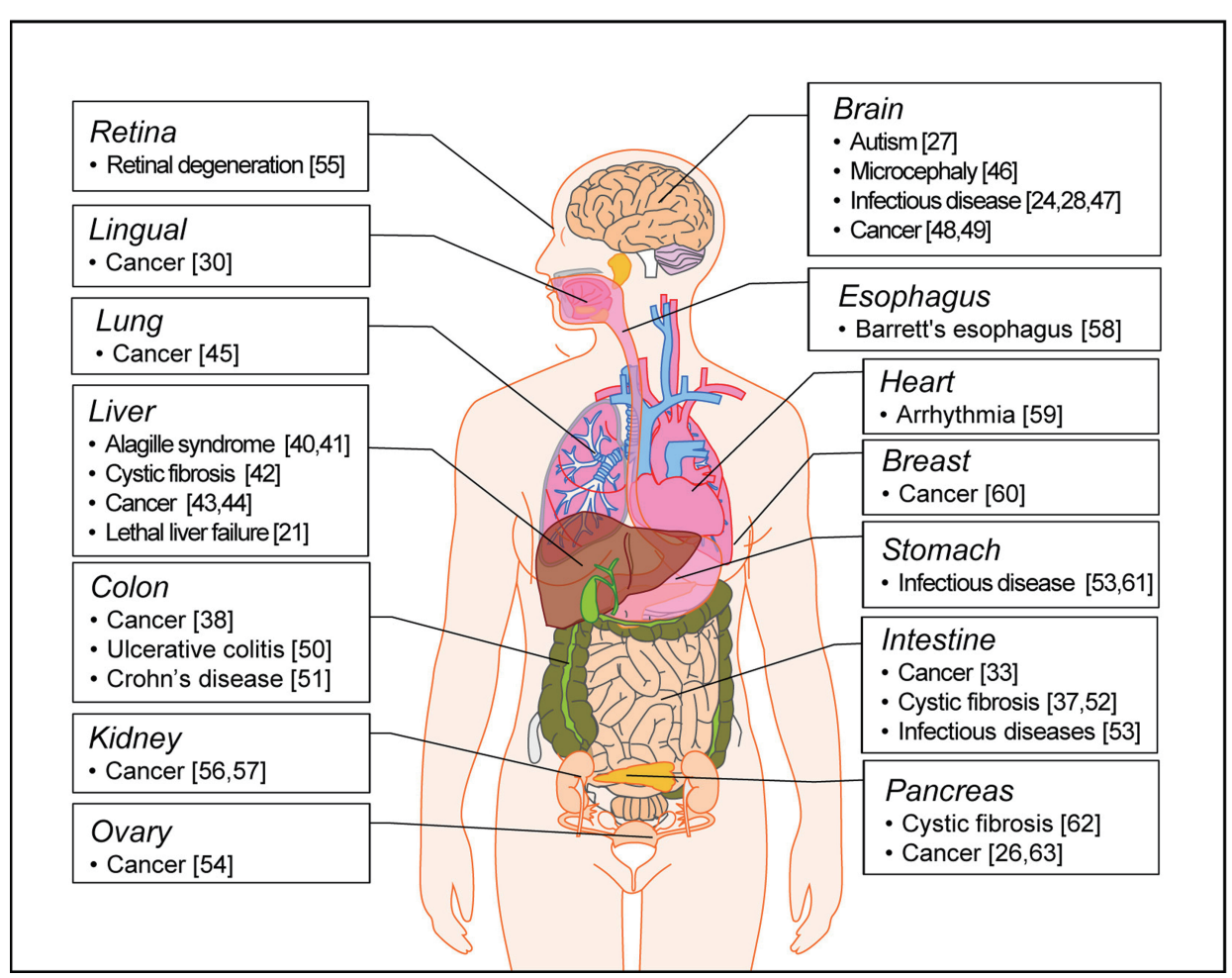

Fig. 2. Establishment of human disease modeling using organoids. The human disease organoids currently established from the pluripotent stem cells and tissues. References are indicated in brackets. 
and Erasmus MC (Fig. 5).

\section{Global technology trends with respect to organoids for drug screening technology}

To analyze technology patent trends related to "drug screening technology using organoids", the WIPS ON Patent search DB (https://www.wipson.com/) was used to search for the disclosed/ registered patents in the Republic of Korea (KR), the United States of America (US), Europe (EP), Japan (JP), and China (CN), which were submitted before 10th September, 2017. A total of 870 patents were screened. We performed filtering to eliminate noise for

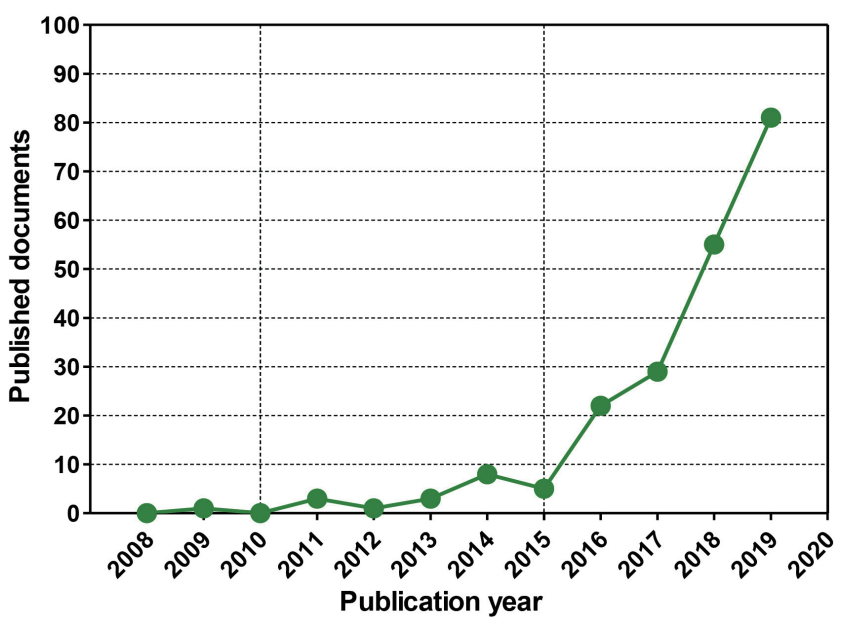

Fig. 3. Status of documents related to nonclinical testing using organoids by year. Global scientific trends in organoid research. A summary of the publications on organoids that are indexed in Scopus according to publication output by year from 2008 to 2019 (Searched date: December 13, 2019).
870 preprocessed data retrieved. The noise rejection criteria were set as follows: records i) with respect to tissue transplantation, ii) with respect to plant cultivation, iii) with respect to cancer treatment constructions, iv) with respect to cellular construction, and v) with respect to stem cell differentiation, were judged and filtered as noise. Next, the effective patents were selected by dividing the methods by tissue generation, 3D cell culture method, and tissue or 3D cell culture device/system, using organoids for (1) drug screening, (2) safety evaluation, or (3) efficacy evaluation of drug candidates. In particular, organoids created from all organs were searched. Even if no information related to drug screening was available within the scope of the search, the patent was iden-

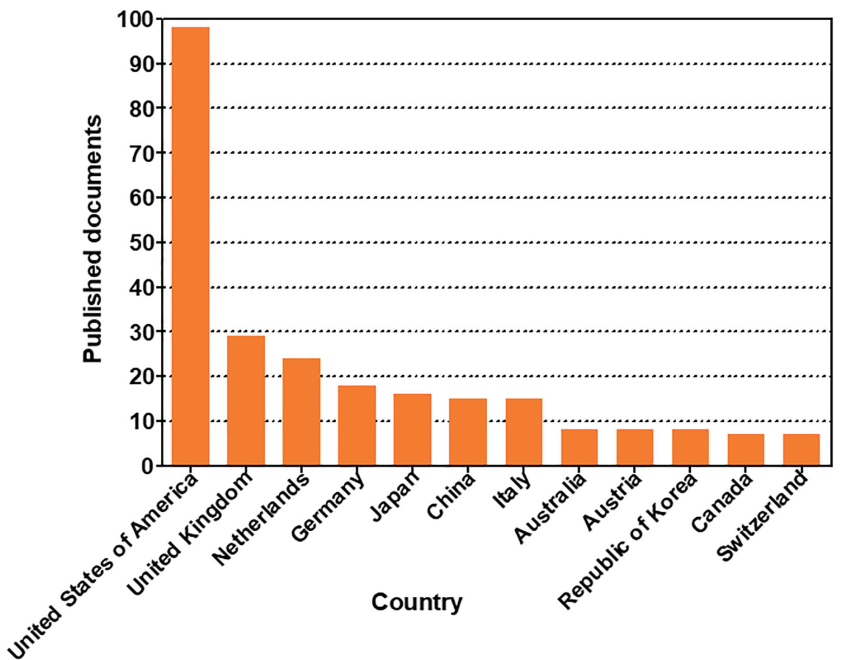

Fig. 4. Status of documents related to nonclinical testing using organoids by country. A summary of the publications on organoids that are indexed in Scopus according to the 12 most frequent affiliation countries of the authors from 2008 to 2019.

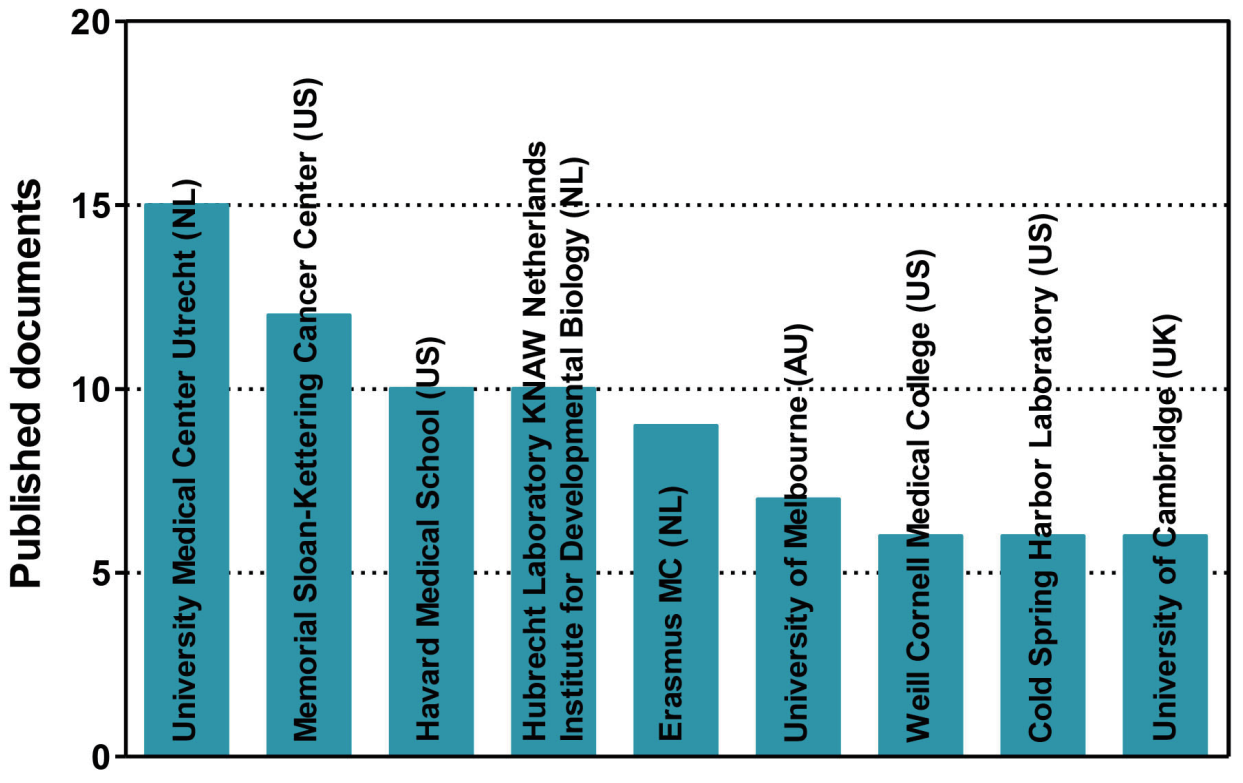

Institution
Fig. 5. Status of documents related to nonclinical testing using organoids by institution. A summary of the publications on organoids that are indexed in Scopus according to the 9 most frequent affiliation countries of the authors from 2008 to 2019. NL, the Netherlands; US, the United States of America; AU, Australia; UK, the United Kingdom. 
tified as valid patent if it stated that the organoid could be applied to drug screening.

The patent classification resulted in a total of 335 patents related to drug screening using organoids (Fig. 6). The highest percentage of patents was related to 3D cell culture, a total of 188 cases. Patents related to $3 \mathrm{D}$ cell culture represented the largest number in 2014, and the number has been decreasing since 2015. There was a total of 144 patents related to tissue generation. In most countries, the number of patent applications has increased since 2009. The lowest number of patents, thirty-three, were related to devices and systems involving tissue generation or 3D cell culture. In 2011, there were many applications filed in the United States of America, the Republic of Korea, and China.

\section{DEVELOPMENT OF NON-CLINICAL TESTING MODELS USING BIOMIMETIC CHIPS}

\section{Biomimetic organ/tissue chip technology}

The biomimetic organ chip is a model that replicates the physiological and mechanical functions of human organs. Fine connections between living human cells are manipulated to control the organ's long-term characteristics or internal cell size, using microfluidic chip technology derived from the semiconductor industry. We summarize the advantages and disadvantages of 2D cell culture models, 3D cell culture models, and microfluidic chip

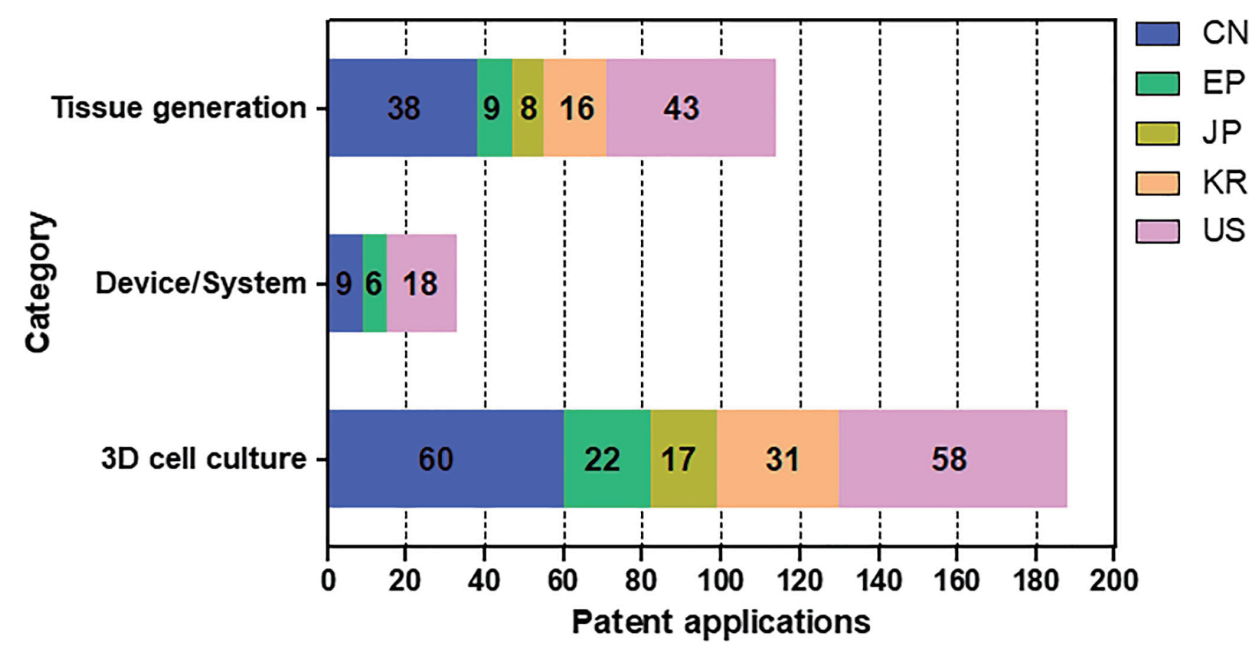

Fig. 6. Number of patent applications by category and country of organoids for a drug screening. The effective patent classification resulted in a total of 335 patents related to a drug screening using organoids. They were divided tissue generation, 3D cell culture method, and tissue or 3D cell culture device/system, using organoids for drug screening, safety evaluation, and efficacy evaluation of drug candidates. The Republic of Korea (KR), the United States of America (US), Europe (EP), Japan (JP), and China (CN).

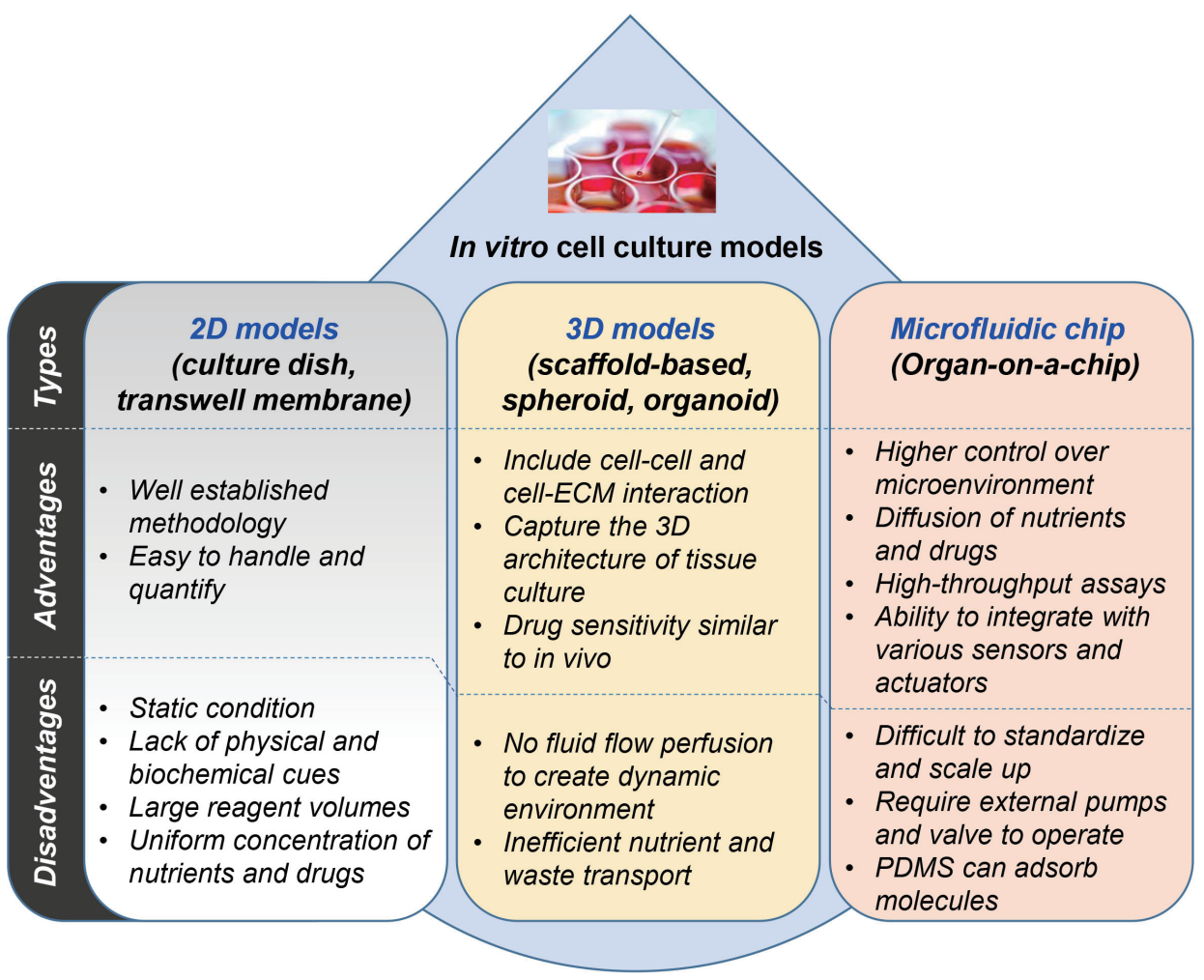

Fig. 7. Comparison of in vitro cell culture models. Summarization of advantages/disadvantages in various cell culture systems with 2D models, 3D models, and microfluidics models. 
models in Fig. 7.

Experiments that were not possible using only cell culture models are possible, including the study of metabolites produced, exchanged, and consumed within tissues, the study of developmental biological signaling systems, and the study of interactions between tissues simulating the dynamics of blood circulation. These experiments are expected to contribute to reduce the gap between in vitro and in vivo experimental environments. In addition, organs-on-a-chip can be used as a candidate drug screening platform at the nonclinical testing stage by allowing drug reactions to be monitored in a similar way to human physiology [70,71].

Research into the development of microfluidic chip platforms for drug screening has been carried out in a variety of countries, such as the United States of America and China. At the International University of Florida in the US, a biosensor that can measure nanomaterial toxicity at the cellular level in real-time can obtain quantitative information about multiple samples at a time [72]. The National Center for Advanced Translational Science (NCATS) has been developing tissue-on-a-chip for drug screening programs since 2011, in collaboration with the National Institutes of Health, the Defense Development, and the FDA [73]. In October 2016 NCATS announced a plan to develop tissue chips for disease modeling and efficacy testing, that could support further development of human disease tissue chip models imitating the pathology of major human organs and tissues. The

Table 1. Biomimetic organ-on-a-chip developed for drug screening

\begin{tabular}{|c|c|c|}
\hline Organ/system & Type of chips & Characteristics \\
\hline \multirow[t]{2}{*}{ Brain } & $\begin{array}{l}\text { Brain development } \\
\text { on a chip }\end{array}$ & $\begin{array}{l}\text { Multiple types of brain cells including neurons, astrocytes, and oligodendrocytes, } \\
\text { and endothelial cells are cultured in the chip system }\end{array}$ \\
\hline & $\begin{array}{l}\text { Blood-brain barrier } \\
\text { on a chip }\end{array}$ & $\begin{array}{l}\text { The brain cells and blood vessels are separated by a membrane that acts like the } \\
\text { blood-brain barrier }\end{array}$ \\
\hline Heart & Heart on a chip & $\begin{array}{l}\text { The human iPSC-derived heart tissue in the chip is beating as a heart in the human } \\
\text { body }\end{array}$ \\
\hline Muscle & Muscle on a chip & The muscle cells to multiply and self-organize into bio-engineered muscle bundles \\
\hline \multirow[t]{2}{*}{ Lungs } & Lungs on a chip & $\begin{array}{l}\text { The bronchial smooth muscle cells (SMCs) based on an airway are in a chip to } \\
\text { establish a healthy airway }\end{array}$ \\
\hline & & $\begin{array}{l}\text { The healthy bronchial SMCs treated with a chemical (IL-13) to establish an asthmatic } \\
\text { airway }\end{array}$ \\
\hline \multirow[t]{3}{*}{ Liver } & Liver on a chip & $\begin{array}{l}\text { A liver on a chip consisted with hepatocytes, stellate cells, Kupffer cells, and } \\
\text { endothelial cells }\end{array}$ \\
\hline & Liver and heart on a chip & The human heart and liver tissues derived from hiPSC are on a chip \\
\hline & $\begin{array}{l}\text { Liver, heart and } \\
\text { microvessels on a chip }\end{array}$ & $\begin{array}{l}\text { The iPSC-derived liver cells added to a special biomaterial to create a liver module } \\
\text { and integrated with similar modules with cardiac cells or microvasculature }\end{array}$ \\
\hline Kidneys & Kidney on a chip & $\begin{array}{l}\text { The tiny human blood vessels were placed on a device that mimics the environment } \\
\text { inside the human kidney }\end{array}$ \\
\hline $\begin{array}{l}\text { Gastrointestinal } \\
\text { system }\end{array}$ & Gut on a chip & $\begin{array}{l}\text { It consists of gut tissue and nerves that stimulate the action of smooth muscle that } \\
\text { controls gut motility }\end{array}$ \\
\hline $\begin{array}{l}\text { Female reproductive } \\
\text { system }\end{array}$ & $\begin{array}{l}\text { Female reproductive } \\
\text { tract on a chip }\end{array}$ & $\begin{array}{l}\text { The top layer of the chip consists of multiple components that individually support } \\
\text { the cervix, fallopian tubes, uterus and ovaries, which are integrated on the } \\
\text { platform. The bottom two layers hold the tiny channels and ports that mimic the } \\
\text { human environment }\end{array}$ \\
\hline \multirow[t]{2}{*}{ Blood vessels } & Blood vessels on a chip & $\begin{array}{l}\text { The bioengineered vessels can deliver oxygen and nutrients into the tissue, and } \\
\text { contract and dilate in the human body do to help regulate body temperature and } \\
\text { metabolism }\end{array}$ \\
\hline & Microvessels on a chip & $\begin{array}{l}\text { Functional microvessels derived from iPSC form networks capable of fluid flow and } \\
\text { deliver oxygen and nutrients to tissues }\end{array}$ \\
\hline Fat (adipose) & Adipose tissue on a chip & Human adipose tissue is on a 3D chip system \\
\hline Skin & Skin on a chip & $\begin{array}{l}\text { The iPSCs-derived skin cells in a 3D chip have transformed into different types of } \\
\text { skin cells and organized themselves into layers as actual human skin }\end{array}$ \\
\hline \multirow[t]{3}{*}{ Disease models } & $\begin{array}{l}\text { Metastatic breast cancer } \\
\text { in the liver }\end{array}$ & $\begin{array}{l}\text { The breast cancer cells are placed on the liver chip system seeded to create a model } \\
\text { of metastatic breast cancer in the liver }\end{array}$ \\
\hline & $\begin{array}{l}\text { Rare heart and muscle } \\
\text { condition }\end{array}$ & $\begin{array}{l}\text { The cardiac chips using iPSCs from a patient with Barth syndrome displayed a } \\
\text { weakened heartbeat and poorly organized structure that mimics a Barth syndrome } \\
\text { patient's heart }\end{array}$ \\
\hline & Tumor with blood vessels & $\begin{array}{l}\text { The tumor chip includes functioning blood vessels, which tumors in the body need } \\
\text { to stay alive }\end{array}$ \\
\hline
\end{tabular}

Various kinds of tissue-on-a-chips for drug screening programs developed by the Center for Advanced Translational Science (NCATS), US. hiPSC, human induced pluripotent stem cell. The information on the table was prepared by referring to the contents posted on the NCATS website (https://ncats.nih.gov/tissuechip/chip/) in August 2020. 
goals of this new plan are (1) to support the development of in vitro disease models using primary tissue or patient-derived induced pluripotent stem cells in a tissue/organ chip platform, (2) to conduct preliminary tests to determine whether these models are related to real diseases, and (3) to carry out the validation of candidate drugs [74]. To date, the NCATS has developed many tissues-on-a-chips including brain [75], heart [76], muscle [77], lung [78], and liver [79] for a variety of drug screening programs. The tissue-on-a-chips for drug screening programs developed by the NCATS were summarized in Table 1.

The Chinese Academy of Sciences has developed an effective cell capture method for cytotoxicity experiments. Cells captured in the eight Micronet structures (microsieves) contained in each chamber can be tested under the same conditions for each group of toxicity tests [80]. The Biotechnology Research Institute, National Research Institute, National Research Council Canada has developed a cell-based chip that consists of eight culture chambers, and can detect the reactivity of cells according to the concentration and treatment time of an administered drug through impedance measurements [81]. At Simon Fraser University in Canada, cells obtained from the same host were also used to form cell retention structures in fine panels to conduct safety assessments of drugs from single cells, in order to minimize the sensitivity of each cell to The Dalian Institute of China produces HTS sensors, and at the same time processes various drugs at different concentrations to analyze the physiological response of cells using tubes [82]. The University of Leipzig, the Center for Biomedical Sciences and the Center for Biomedical Science in Germany, has developed electrochemical microcavity chips that can capture cells and allow 3D cell culture and drug testing without the adhesion of cells and electrodes [83]. It is possible to shorten the clinical trial process of anticancer drugs by modelling the metastasis process of cancer cells by providing a similar environment in vivo. Boston Children's Hospital and Harvard University's Wyss Institute developed a lung-on-a-chip similar to human lung structures [84]. This chip can be used in the differentiation and culture of stem cells, and is expected to be useful in the screening of lung-related disease drugs. Donghua University in China developed a chip that is stable for neurotransmitter transmission signals during neuron differentiation using graphene, a substance with high electrical conductivity, and can reproduce soft tissue in vivo through cross-connections with poly-dimethylacrylamide [85]. The chip can recognize not only the differentiation of nerve cells but also the efficiency of differentiation and the signal transmission system between neurons through electrical signals [86]. The University of Münster, Germany, has developed a biosensor to measure the toxicity of material in real-time using specific changes in the form of cells caused by impedance [87].

In the U.S., a sensor was developed which changes in response to electrochemical resistance values mammalian cells are cultured the chip is injected with water containing toxins. The chip is used not only in the pharmaceutical sector but also in the envi- ronment, food, and military industries due to its convenience and portability [88].

In the Republic of Korea, the Korea Institute of Science and Technology has developed a sensor that measures and detects micro-wavelengths using multi-electrode array network activity between neurons [89]. The chip has the advantage of producing a lot of results under a variety of experimental conditions, and can be utilized in a variety of fields, such as the evaluation of safety and usability and the cell culture status of a drug. Sogang University produced an electrochemical biosensor capable of screening drugs with high sensitivity by fixing cells directly on a gold electrode [90].

Among the companies and schools currently studying organspecific biomimetic organ-on-a-chips, the number of companies and schools developing skin chips is the largest (Fig. 8), because they can be used in the cosmetics industry.

\section{Global technology trends in biomimetic organs-on-a- chip}

To search for patents in the field of biomimetic chips, search keywords were organized and searched using chip-related synonyms, including keywords related to stem cells, organoids, human organs, or spheroids. In addition, five categories of organand disease-specific chips were classified: heart, liver, brain, lung, and multi-organ.

The annual trend of applications for effective biomimetic chip patents is 59 cases (94\%) for multi-organ and 3 cases (5\%) for lung, 1 case of liver (1\%), and 0 cases of heart ( $0 \%$ ), and brain ( $0 \%)$ (Fig. 9A). The overall trend is increasing. The number of patents centered on multi-organ technology increased significantly between 2012 and 2015 (Fig. 9B). There are many technologies that

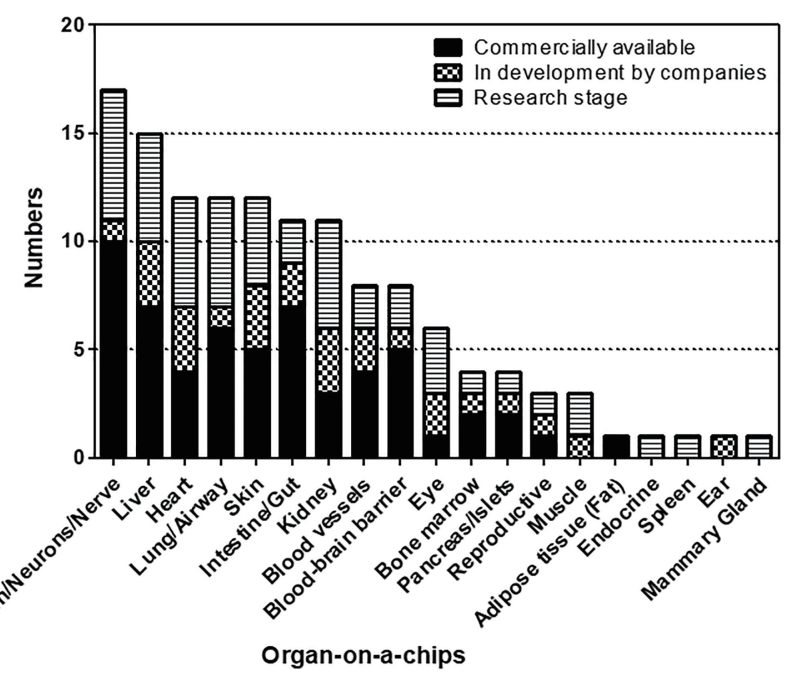

Fig. 8. Number of companies and schools developing organ-ona-chips. Excerpted from the Organs-on-chips: From Technologies to Market, YOLE (April, 2017) and modified the graph format. 

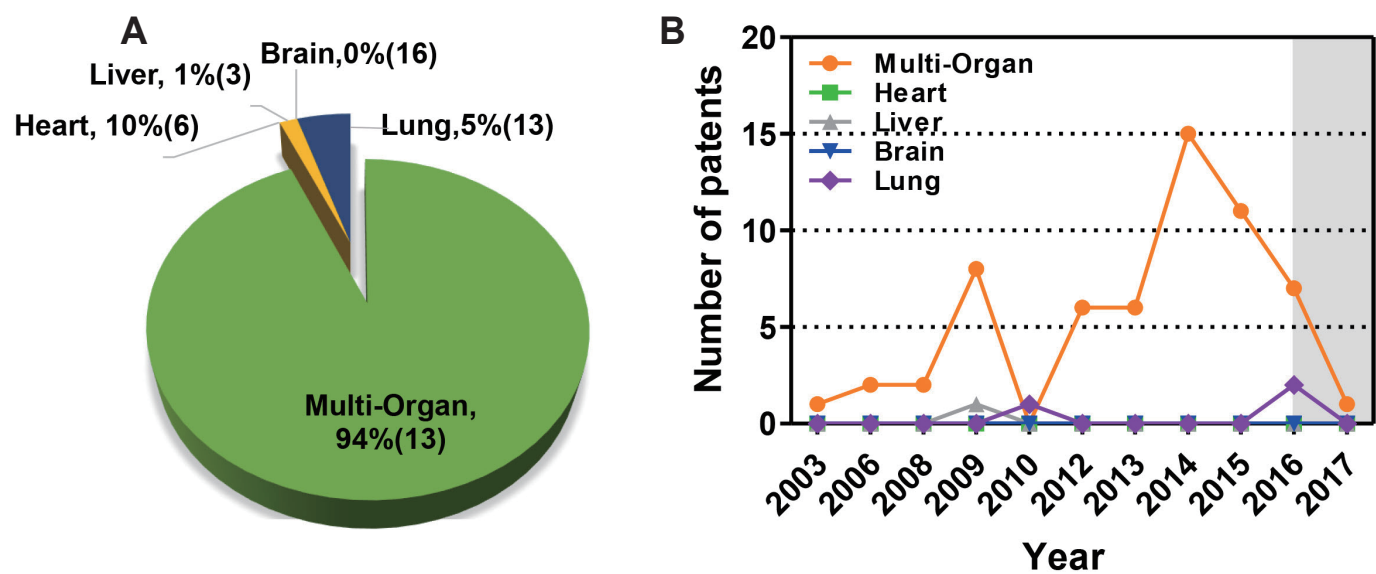

Fig. 9. Global technology trends of biomimetic organ-on-a-chip by organ. (A) Percentage of patents for biomimetic organ chips by type of organ from 2003 to 2017. (B) The annual trend of applications for effective biomimetic chip patents by organ types. The gray section represents the unpublished section of the patent.

A

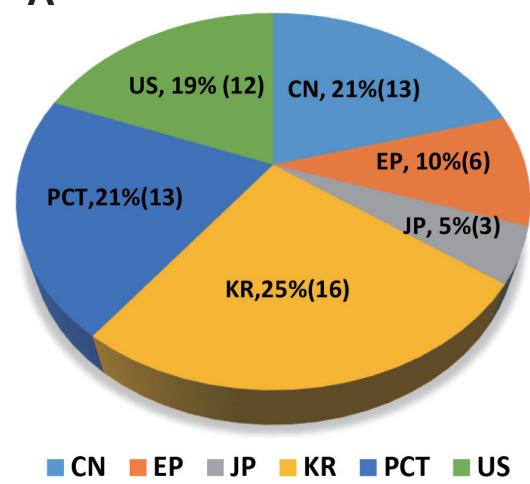

B

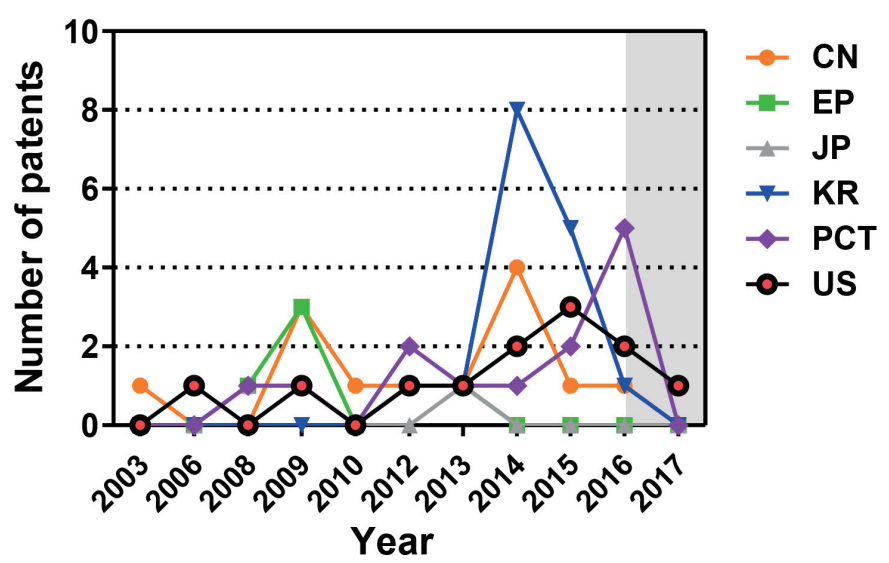

Fig. 10. Patent applications trend by country and year. (A) Percentage of patents for biomimetic organ chips by country from 2003 to 2017 . (B) The annual trend of applications for effective biomimetic chip patents by country. The gray section represents the unpublished section of the patent. CN, China; EP, Europe; JP, Japan; KR, Republic of Korea; PCT, Patent Cooperation Treaty; US, United States of America.

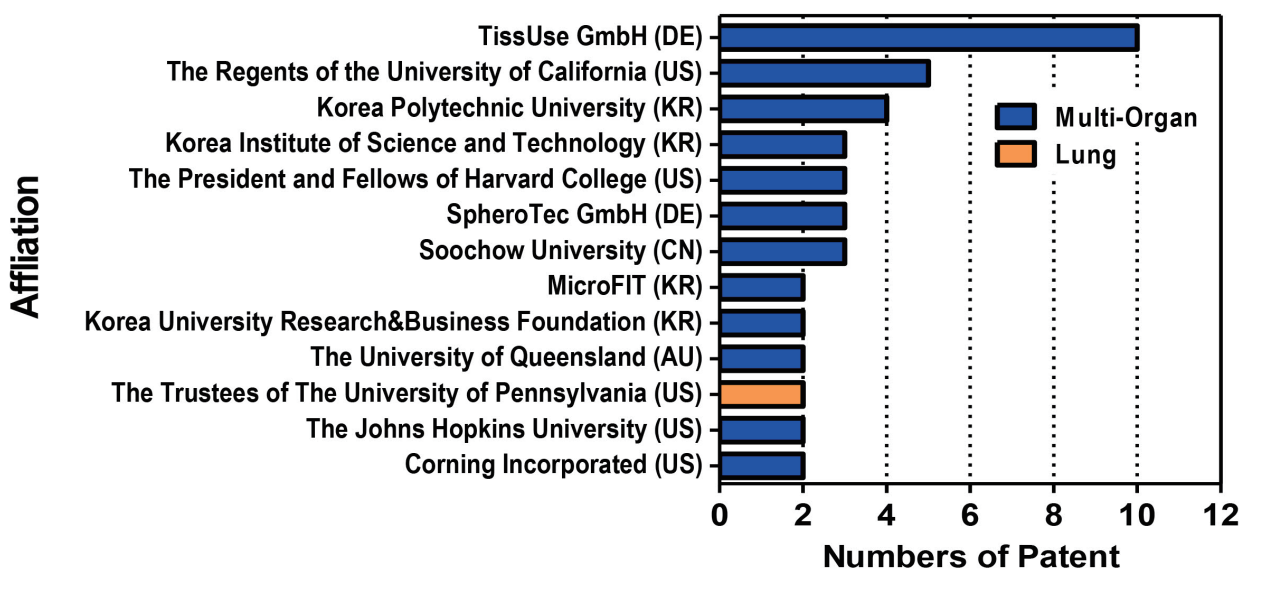

Fig. 11. Number of patent applications by institution. A summary of the patents on organ-related chip that are indexed in WIPS ON search site according to the 10 most frequent affiliation (13 institutions are reported due to a tie for tenth place). DE, Germany; AU, Australia; CN, China; KR, Republic of Korea; US, United States of America. correspond to multi-organ as chip-oriented technology, rather than being limited to specific diseases. Overall, multi-organ technology accounted for more patents than those related to the heart, liver, brain, and lungs.

Among valid patents for biomimetic organ-on-a-chip are 16 cases (25\%) in the Republic of Korea, 13 cases (21\%) in China, 13 
cases (21\%) from the Patent Cooperation Treaty (PCT), 12 cases (19\%) in the U.S., 6 cases (9\%) in Europe, and 3 cases (5\%) in Japan (Fig. 10A). In particular, the number of patents filed in the Republic of Korea (KR) increased significantly in 2014, which can be seen as due to a high level of chip-making technology based on this country's excellence in electronic and material technologies. Recent trends are seen as active applications for China, and the United States of America in 2015, and the PCT in 2016 (Fig. 10B). As shown in Fig. 11, TissUse GmbH in Germany is the institute with the largest number of patent applications, followed by the Regents of the University of California in the U.S. and the Korea Polytechnic University in the Republic of Korea.

\section{CONCLUSIONS}

An organoid simulates each organ's environment in the complex human body or animal, and has similar characteristics to the actual organ. Organoids can produce more accurate results than two-dimensional cell models when assessing the reactivity of drugs. In addition, cell death, viability, division, and ligands according to the movement of molecules, can produce information such as the interactions of receptors, the activity of the genome and proteins, and organoid structure. Combining these advantages with tissue engineering, biomimetic tissue chips and biomimetic organs-on-a-chip are rapidly being developed. Organoids are available for alternative toxicity studies in non-clinical trials, in keeping with animal use regulations, and are more predictable at a lower cost than animal models. It is possible to overcome the differences between heterogeneous drug reactions that exist between humans and animals.

However, there are still challenges to overcome in order to develop organoids and biomimetic organs-on-a-chip. In order for this model to be utilized in drug evaluation technology, standards are needed for the management of cells, production technology, and quality evaluation of the chip models by the organ/ drug, and there is a need to verify the test methods using known control drugs. If the regulations related to human stem cells and biomimetic organs-on-a-chip are set at a national level, it will be possible to test the potential effects of various substances, such as pre-clinical drugs, in the field of drug development, using nonanimal models.

\section{ACKNOWLEDGEMENTS}

This research was supported by a grant (17172MFDS216) from Ministry of Food and Drug Safety in 2017. In addition, this research was also supported by a grant (19172MFDS168) from Ministry of Food and Drug Safety in 2020.

\section{CONFLICTS OF INTEREST}

The authors declare no conflicts of interest.

\section{REFERENCES}

1. Rawlins MD. Cutting the cost of drug development? Nat Rev Drug Discov. 2004;3:360-364.

2. Hisha $H$, Ueno H. Organoid culture of lingual epithelial cells in a three-dimensional matrix. Methods Mol Biol. 2019;1576:93-99.

3. Fentem J, Chamberlain M, Sangster B. The feasibility of replacing animal testing for assessing consumer safety: a suggested future direction. Altern Lab Anim. 2004;32:617-623.

4. Heuberger R, Petty M, Huntingford J. Companion animal owner perceptions, knowledge, and beliefs regarding pain management in end-of-life care. Top Companion Anim Med. 2016;31:152-159.

5. Jensen J, Hyllner J, Björquist P. Human embryonic stem cell technologies and drug discovery. J Cell Physiol. 2009;219:513-519.

6. Caspi O, Itzhaki I, Kehat I, Gepstein A, Arbel G, Huber I, Satin J, Gepstein L. In vitro electrophysiological drug testing using human embryonic stem cell derived cardiomyocytes. Stem Cells Dev. 2009;18:161-172.

7. Centeno EGZ, Cimarosti H, Bithell A. 2D versus $3 D$ human induced pluripotent stem cell-derived cultures for neurodegenerative disease modelling. Mol Neurodegener. 2018;13:27.

8. Ranga A, Gjorevski N, Lutolf MP. Drug discovery through stem cell-based organoid models. Adv Drug Deliv Rev. 2014;69-70:19-28.

9. Chen KG, Mallon BS, Park K, Robey PG, McKay RDG, Gottesman MM, Zheng W. Pluripotent stem cell platforms for drug discovery. Trends Mol Med. 2018;24:805-820.

10. Lancaster MA, Knoblich JA. Organogenesis in a dish: modeling development and disease using organoid technologies. Science. 2014;345:1247125.

11. Sato T, Vries RG, Snippert HJ, van de Wetering M, Barker N, Stange DE, van Es JH, Abo A, Kujala P, Peters PJ, Clevers H. Single Lgr5 stem cells build crypt-villus structures in vitro without a mesenchymal niche. Nature. 2009;459:262-265.

12. Taguchi A, Kaku Y, Ohmori T, Sharmin S, Ogawa M, Sasaki H, Nishinakamura R. Redefining the in vivo origin of metanephric nephron progenitors enables generation of complex kidney structures from pluripotent stem cells. Cell Stem Cell. 2014;14:53-67.

13. Xia Y, Nivet E, Sancho-Martinez I, Gallegos T, Suzuki K, Okamura D, Wu MZ, Dubova I, Esteban CR, Montserrat N, Campistol JM, Izpisua Belmonte JC. Directed differentiation of human pluripotent cells to ureteric bud kidney progenitor-like cells. Nat Cell Biol. 2013;15:1507-1515.

14. Clevers H. Modeling development and disease with organoids. Cell. 2016;165:1586-1597.

15. Forbester JL, Goulding D, Vallier L, Hannan N, Hale C, Pickard D, Mukhopadhyay S, Dougan G. Interaction of Salmonella enterica serovar Typhimurium with intestinal organoids derived from human induced pluripotent stem cells. Infect Immun. 2015;83:2926-2934.

16. Leslie JL, Huang S, Opp JS, Nagy MS, Kobayashi M, Young VB, Spence JR. Persistence and toxin production by Clostridium difficile within human intestinal organoids result in disruption of epithelial 
paracellular barrier function. Infect Immun. 2015;83:138-145.

17. Spence JR, Mayhew CN, Rankin SA, Kuhar MF, Vallance JE, Tolle K, Hoskins EE, Kalinichenko VV, Wells SI, Zorn AM, Shroyer NF, Wells JM. Directed differentiation of human pluripotent stem cells into intestinal tissue in vitro. Nature. 2011;470:105-109.

18. Crespo M, Vilar E, Tsai SY, Chang K, Amin S, Srinivasan T, Zhang T, Pipalia NH, Chen HJ, Witherspoon M, Gordillo M, Xiang JZ, Maxfield FR, Lipkin S, Evans T, Chen S. Colonic organoids derived from human induced pluripotent stem cells for modeling colorectal cancer and drug testing. Nat Med. 2017;23:878-884.

19. Prior N, Inacio P, Huch M. Liver organoids: from basic research to therapeutic applications. Gut. 2019;68:2228-2237.

20. Sampaziotis F, de Brito MC, Madrigal P, Bertero A, Saeb-Parsy K, Soares FAC, Schrumpf E, Melum E, Karlsen TH, Bradley JA, Gelson WT, Davies S, Baker A, Kaser A, Alexander GJ, Hannan NRF, Vallier L. Cholangiocytes derived from human induced pluripotent stem cells for disease modeling and drug validation. Nat Biotechnol. 2015;33:845-852.

21. Takebe T, Sekine K, Enomura M, Koike H, Kimura M, Ogaeri T, Zhang RR, Ueno Y, Zheng YW, Koike N, Aoyama S, Adachi Y, Taniguchi $\mathrm{H}$. Vascularized and functional human liver from an iPSCderived organ bud transplant. Nature. 2013;499:481-484.

22. Dye BR, Hill DR, Ferguson MA, Tsai YH, Nagy MS, Dyal R, Wells JM, Mayhew CN, Nattiv R, Klein OD, White ES, Deutsch GH, Spence JR. In vitro generation of human pluripotent stem cell derived lung organoids. Elife. 2015;4:e05098.

23. Firth AL, Menon T, Parker GS, Qualls SJ, Lewis BM, Ke E, Dargitz CT, Wright R, Khanna A, Gage FH, Verma IM. Functional gene correction for cystic fibrosis in lung epithelial cells generated from patient iPSCs. Cell Rep. 2015;12:1385-1390.

24. Garcez PP, Loiola EC, Madeiro da Costa R, Higa LM, Trindade P, Delvecchio R, Nascimento JM, Brindeiro R, Tanuri A, Rehen SK. Zika virus impairs growth in human neurospheres and brain organoids. Science. 2016;352:816-818.

25. Hohwieler M, Illing A, Hermann PC, Mayer T, Stockmann M, Perkhofer L, Eiseler T, Antony JS, Müller M, Renz S, Kuo CC, Lin Q, Sendler M, Breunig M, Kleiderman SM, Lechel A, Zenker M, Leichsenring M, Rosendahl J, Zenke M, et al. Human pluripotent stem cell-derived acinar/ductal organoids generate human pancreas upon orthotopic transplantation and allow disease modelling. Gut. 2017;66:473-486.

26. Huang L, Holtzinger A, Jagan I, BeGora M, Lohse I, Ngai N, Nostro C, Wang R, Muthuswamy LB, Crawford HC, Arrowsmith C, Kalloger SE, Renouf DJ, Connor AA, Cleary S, Schaeffer DF, Roehrl M, Tsao MS, Gallinger S, Keller G, et al. Ductal pancreatic cancer modeling and drug screening using human pluripotent stem cell- and patient-derived tumor organoids. Nat Med. 2015;21:1364-1371.

27. Mariani J, Coppola G, Zhang P, Abyzov A, Provini L, Tomasini L, Amenduni M, Szekely A, Palejev D, Wilson M, Gerstein M, Grigorenko EL, Chawarska K, Pelphrey KA, Howe JR, Vaccarino FM. FOXG1-dependent dysregulation of GABA/glutamate neuron differentiation in autism spectrum disorders. Cell. 2015;162:375-390.

28. Qian X, Nguyen HN, Jacob F, Song H, Ming GL. Using brain organoids to understand Zika virus-induced microcephaly. Development. 2017;144:952-957.

29. Drost J, Clevers H. Translational applications of adult stem cellderived organoids. Development. 2017;144:968-975.
30. Hisha H, Tanaka T, Kanno S, Tokuyama Y, Komai Y, Ohe S, Yanai $\mathrm{H}$, Omachi T, Ueno H. Establishment of a novel lingual organoid culture system: generation of organoids having mature keratinized epithelium from adult epithelial stem cells. Sci Rep. 2013;3:3224.

31. Barker N, Huch M, Kujala P, van de Wetering M, Snippert HJ, van Es JH, Sato T, Stange DE, Begthel H, van den Born M, Danenberg E, van den Brink S, Korving J, Abo A, Peters PJ, Wright N, Poulsom $\mathrm{R}$, Clevers H. Lgr5(+ve) stem cells drive self-renewal in the stomach and build long-lived gastric units in vitro. Cell Stem Cell. 2010;6:2536.

32. Bartfeld S, Bayram T, van de Wetering M, Huch M, Begthel H, Kujala P, Vries R, Peters PJ, Clevers H. In vitro expansion of human gastric epithelial stem cells and their responses to bacterial infection. Gastroenterology. 2015;148:126-136.e6.

33. Drost J, van Jaarsveld RH, Ponsioen B, Zimberlin C, van Boxtel R, Buijs A, Sachs N, Overmeer RM, Offerhaus GJ, Begthel H, Korving J, van de Wetering M, Schwank G, Logtenberg M, Cuppen E, Snippert HJ, Medema JP, Kops GJ, Clevers H. Sequential cancer mutations in cultured human intestinal stem cells. Nature. 2015;521:43-47.

34. Fair KL, Colquhoun J, Hannan NRF. Intestinal organoids for modelling intestinal development and disease. Philos Trans $R$ Soc Lond B Biol Sci. 2018;373:20170217.

35. Xu H, Lyu X, Yi M, Zhao W, Song Y, Wu K. Organoid technology and applications in cancer research. J Hematol Oncol. 2018;11:116.

36. Papafragkou E, Hewitt J, Park GW, Greening G, Vinjé J. Challenges of culturing human norovirus in three-dimensional organoid intestinal cell culture models. PLoS One. 2013;8:e63485.

37. Schwank G, Koo BK, Sasselli V, Dekkers JF, Heo I, Demircan T, Sasaki N, Boymans S, Cuppen E, van der Ent CK, Nieuwenhuis EE, Beekman JM, Clevers H. Functional repair of CFTR by CRISPR/ Cas9 in intestinal stem cell organoids of cystic fibrosis patients. Cell Stem Cell. 2013;13:653-658.

38. Sato T, Stange DE, Ferrante M, Vries RG, Van Es JH, Van den Brink S, Van Houdt WJ, Pronk A, Van Gorp J, Siersema PD, Clevers H. Long-term expansion of epithelial organoids from human colon, adenoma, adenocarcinoma, and Barrett's epithelium. Gastroenterology. 2011;141:1762-1772.

39. Dutta D, Heo I, Clevers H. Disease modeling in stem cell-derived 3D organoid systems. Trends Mol Med. 2017;23:393-410.

40. Huch M, Gehart H, van Boxtel R, Hamer K, Blokzijl F, Verstegen MM, Ellis E, van Wenum M, Fuchs SA, de Ligt J, van de Wetering M, Sasaki N, Boers SJ, Kemperman H, de Jonge J, Ijzermans JN, Nieuwenhuis EE, Hoekstra R, Strom S, Vries RR, et al. Long-term culture of genome-stable bipotent stem cells from adult human liver. Cell. 2015;160:299-312.

41. Guan Y, Xu D, Garfin PM, Ehmer U, Hurwitz M, Enns G, Michie S, Wu M, Zheng M, Nishimura T, Sage J, Peltz G. Human hepatic organoids for the analysis of human genetic diseases. JCI Insight. 2017;2:e94954.

42. Fiorotto R, Amenduni M, Mariotti V, Fabris L, Spirli C, Strazzabosco M. Src kinase inhibition reduces inflammatory and cytoskeletal changes in $\Delta \mathrm{F} 508$ human cholangiocytes and improves cystic fibrosis transmembrane conductance regulator correctors efficacy. Hepatology. 2018;67:972-988.

43. Broutier L, Mastrogiovanni G, Verstegen MM, Francies HE, Gavarró LM, Bradshaw CR, Allen GE, Arnes-Benito R, Sidorova O, Gaspersz MP, Georgakopoulos N, Koo BK, Dietmann S, Davies SE, 
Praseedom RK, Lieshout R, IJzermans JNM, Wigmore SJ, SaebParsy K, Garnett MJ, et al. Human primary liver cancer-derived organoid cultures for disease modeling and drug screening. Nat Med. 2017;23:1424-1435.

44. Sun L, Wang Y, Cen J, Ma X, Cui L, Qiu Z, Zhang Z, Li H, Yang RZ, Wang C, Chen X, Wang L, Ye Y, Zhang H, Pan G, Kang JS, Ji Y, Zheng YW, Zheng S, Hui L. Modelling liver cancer initiation with organoids derived from directly reprogrammed human hepatocytes. Nat Cell Biol. 2019;21:1015-1026.

45. Kim M, Mun H, Sung CO, Cho EJ, Jeon HJ, Chun SM, Jung DJ, Shin TH, Jeong GS, Kim DK, Choi EK, Jeong SY, Taylor AM, Jain S, Meyerson M, Jang SJ. Patient-derived lung cancer organoids as in vitro cancer models for therapeutic screening. Nat Commun. 2019;10:3991.

46. Lancaster MA, Renner M, Martin CA, Wenzel D, Bicknell LS, Hurles ME, Homfray T, Penninger JM, Jackson AP, Knoblich JA. Cerebral organoids model human brain development and microcephaly. Nature. 2013;501:373-379.

47. Wells MF, Salick MR, Wiskow O, Ho DJ, Worringer KA, Ihry RJ, Kommineni S, Bilican B, Klim JR, Hill EJ, Kane LT, Ye C, Kaykas A, Eggan K. Genetic ablation of AXL does not protect human neural progenitor cells and cerebral organoids from Zika virus infection. Cell Stem Cell. 2016;19:703-708.

48. Hubert CG, Rivera M, Spangler LC, Wu Q, Mack SC, Prager BC, Couce M, McLendon RE, Sloan AE, Rich JN. A three-dimensional organoid culture system derived from human glioblastomas recapitulates the hypoxic gradients and cancer stem cell heterogeneity of tumors found in vivo. Cancer Res. 2016;76:2465-2477.

49. Ogawa J, Pao GM, Shokhirev MN, Verma IM. Glioblastoma model using human cerebral organoids. Cell Rep. 2018;23:1220-1229.

50. Dotti I, Mora-Buch R, Ferrer-Picón E, Planell N, Jung P, Masamunt MC, Leal RF, Martín de Carpi J, Llach J, Ordás I, Batlle E, Panés J, Salas A. Alterations in the epithelial stem cell compartment could contribute to permanent changes in the mucosa of patients with ulcerative colitis. Gut. 2017;66:2069-2079.

51. d'Aldebert E, Quaranta M, Sébert M, Bonnet D, Kirzin S, Portier G, Duffas JP, Chabot S, Lluel P, Allart S, Ferrand A, Alric L, RacaudSultan C, Mas E, Deraison C, Vergnolle N. Characterization of human colon organoids from inflammatory bowel disease patients. Front Cell Dev Biol. 2020;8:363.

52. Dekkers JF, Berkers G, Kruisselbrink E, Vonk A, de Jonge HR, Janssens HM, Bronsveld I, van de Graaf EA, Nieuwenhuis EE, Houwen RH, Vleggaar FP, Escher JC, de Rijke YB, Majoor CJ, Heijerman HG, de Winter-de Groot KM, Clevers H, van der Ent CK, Beekman JM. Characterizing responses to CFTR-modulating drugs using rectal organoids derived from subjects with cystic fibrosis. Sci Transl Med. 2016;8:344ra84.

53. Finkbeiner SR, Zeng XL, Utama B, Atmar RL, Shroyer NF, Estes MK. Stem cell-derived human intestinal organoids as an infection model for rotaviruses. mBio. 2012;3:e00159-e00112.

54. de Witte CJ, Espejo Valle-Inclan J, Hami N, Lõhmussaar K, Kopper O, Vreuls CPH, Jonges GN, van Diest P, Nguyen L, Clevers H, Kloosterman WP, Cuppen E, Snippert HJG, Zweemer RP, Witteveen PO, Stelloo E. Patient-derived ovarian cancer organoids mimic clinical response and exhibit heterogeneous inter- and intrapatient drug responses. Cell Rep. 2020;31:107762.

55. Huang KC, Wang ML, Chen SJ, Kuo JC, Wang WJ, Nhi Nguyen
PN, Wahlin KJ, Lu JF, Tran AA, Shi M, Chien Y, Yarmishyn AA, Tsai PH, Yang TC, Jane WN, Chang CC, Peng CH, Schlaeger TM, Chiou SH. Morphological and molecular defects in human threedimensional retinal organoid model of X-linked juvenile retinoschisis. Stem Cell Reports. 2019;13:906-923.

56. Takasato M, Er PX, Chiu HS, Maier B, Baillie GJ, Ferguson C, Parton RG, Wolvetang EJ, Roost MS, Chuva de Sousa Lopes SM, Little MH. Kidney organoids from human iPS cells contain multiple lineages and model human nephrogenesis. Nature. 2015;526:564-568.

57. Freedman BS, Brooks CR, Lam AQ, Fu H, Morizane R, Agrawal V, Saad AF, Li MK, Hughes MR, Werff RV, Peters DT, Lu J, Baccei A, Siedlecki AM, Valerius MT, Musunuru K, McNagny KM, Steinman TI, Zhou J, Lerou PH, et al. Modelling kidney disease with CRISPRmutant kidney organoids derived from human pluripotent epiblast spheroids. Nat Commun. 2015;6:8715.

58. Trisno SL, Philo KED, McCracken KW, Catá EM, Ruiz-Torres S, Rankin SA, Han L, Nasr T, Chaturvedi P, Rothenberg ME, Mandegar MA, Wells SI, Zorn AM, Wells JM. Esophageal organoids from human pluripotent stem cells delineate Sox2 functions during esophageal specification. Cell Stem Cell. 2018;23:501-515.e7.

59. Nugraha B, Buono MF, von Boehmer L, Hoerstrup SP, Emmert MY. Human cardiac organoids for disease modeling. Clin Pharmacol Ther. 2019;105:79-85.

60. Sachs N, de Ligt J, Kopper O, Gogola E, Bounova G, Weeber F, Balgobind AV, Wind K, Gracanin A, Begthel H, Korving J, van Boxtel R, Duarte AA, Lelieveld D, van Hoeck A, Ernst RF, Blokzijl F, Nijman IJ, Hoogstraat M, van de Ven M, et al. A living biobank of breast cancer organoids captures disease heterogeneity. Cell. 2018;172:373386.e10.

61. Bartfeld S, Clevers H. Organoids as model for infectious diseases: culture of human and murine stomach organoids and microinjection of Helicobacter pylori. J Vis Exp. 2015;(105):53359.

62. Shik Mun K, Arora K, Huang Y, Yang F, Yarlagadda S, Ramananda Y, Abu-El-Haija M, Palermo JJ, Appakalai BN, Nathan JD, Naren AP. Patient-derived pancreas-on-a-chip to model cystic fibrosis-related disorders. Nat Commun. 2019;10:3124.

63. Boj SF, Hwang CI, Baker LA, Chio II, Engle DD, Corbo V, Jager M, Ponz-Sarvise M, Tiriac H, Spector MS, Gracanin A, Oni T, Yu KH, van Boxtel R, Huch M, Rivera KD, Wilson JP, Feigin ME, Öhlund D, Handly-Santana A, et al. Organoid models of human and mouse ductal pancreatic cancer. Cell. 2015;160:324-338.

64. Tuveson D, Clevers H. Cancer modeling meets human organoid technology. Science. 2019;364:952-955.

65. Byrne AT, Alférez DG, Amant F, Annibali D, Arribas J, Biankin AV, Bruna A, Budinská E, Caldas C, Chang DK, Clarke RB, Clevers H, Coukos G, Dangles-Marie V, Eckhardt SG, Gonzalez-Suarez E, Hermans E, Hidalgo M, Jarzabek MA, de Jong S, et al. Interrogating open issues in cancer precision medicine with patient-derived xenografts. Nat Rev Cancer. 2017;17:254-268.

66. Drost J, Clevers H. Organoids in cancer research. Nat Rev Cancer. 2018;18:407-418.

67. van de Wetering M, Francies HE, Francis JM, Bounova G, Iorio F, Pronk A, van Houdt W, van Gorp J, Taylor-Weiner A, Kester L, McLaren-Douglas A, Blokker J, Jaksani S, Bartfeld S, Volckman R, van Sluis P, Li VS, Seepo S, Sekhar Pedamallu C, Cibulskis K, et al. Prospective derivation of a living organoid biobank of colorectal cancer patients. Cell. 2015;161:933-945. 
68. Baker LA, Tiriac H, Clevers H, Tuveson DA. Modeling pancreatic cancer with organoids. Trends Cancer. 2016;2:176-190.

69. Kuo CJ, Curtis C. Organoids reveal cancer dynamics. Nature. 2018;556:441-442.

70. Ishida S. Organs-on-a-chip: current applications and consideration points for in vitro ADME-Tox studies. Drug Metab Pharmacokinet. 2018;33:49-54.

71. Kimura H, Sakai Y, Fujii T. Organ/body-on-a-chip based on microfluidic technology for drug discovery. Drug Metab Pharmacokinet. 2018;33:43-48.

72. Chi CW, Ahmed AR, Dereli-Korkut Z, Wang S. Microfluidic cell chips for high-throughput drug screening. Bioanalysis. 2016;8:921937.

73. Livingston CA, Fabre KM, Tagle DA. Facilitating the commercialization and use of organ platforms generated by the microphysiological systems (Tissue Chip) program through public-private partnerships. Comput Struct Biotechnol J. 2016;14:207-210.

74. Low LA, Tagle DA. Tissue chips to aid drug development and modeling for rare diseases. Expert Opin Orphan Drugs. 2016;4:11131121.

75. Alcendor DJ, Block FE 3rd, Cliffel DE, Daniels JS, Ellacott KL, Goodwin CR, Hofmeister LH, Li D, Markov DA, May JC, McCawley LJ, McLaughlin B, McLean JA, Niswender KD, Pensabene V, Seale KT, Sherrod SD, Sung HJ, Tabb DL, Webb DJ, et al. Neurovascular unit on a chip: implications for translational applications. Stem Cell Res Ther. 2013;4(Suppl 1):S18.

76. Mathur A, Loskill P, Shao K, Huebsch N, Hong S, Marcus SG, Marks N, Mandegar M, Conklin BR, Lee LP, Healy KE. Human iPSC-based cardiac microphysiological system for drug screening applications. Sci Rep. 2015;5:8883.

77. Agarwal A, Goss JA, Cho A, McCain ML, Parker KK. Microfluidic heart on a chip for higher throughput pharmacological studies. Lab Chip. 2013;13:3599-3608.

78. Nesmith AP, Agarwal A, McCain ML, Parker KK. Human airway musculature on a chip: an in vitro model of allergic asthmatic bronchoconstriction and bronchodilation. Lab Chip. 2014;14:3925-3936.

79. Vernetti LA, Senutovitch N, Boltz R, DeBiasio R, Shun TY, Gough A, Taylor DL. A human liver microphysiology platform for investigating physiology, drug safety, and disease models. Exp Biol Med
(Maywood). 2016;241:101-114.

80. Song H, Peng S, Chen T, Zhang B, Wang Z. Cell cytotoxicity analysis of adherent and suspended cancer cells using an integrated microfluidic device. Paper presented at: 2011 4th International Conference on Biomedical Engineering and Informatics (BMEI); 2011 Oct 15-17; Shanghai, China. p. 1051-1054.

81. Male KB, Lachance B, Hrapovic S, Sunahara G, Luong JH. Assessment of cytotoxicity of quantum dots and gold nanoparticles using cell-based impedance spectroscopy. Anal Chem. 2008;80:5487-5493.

82. Zheng GX, Li YJ, Qi LL, Liu XM, Wang H, Yu SP, Wang YH. Marine phytoplankton motility sensor integrated into a microfluidic chip for high-throughput pollutant toxicity assessment. Mar Pollut Bull. 2014;84:147-154.

83. Kloss D, Fischer M, Rothermel A, Simon JC, Robitzki AA. Drug testing on $3 \mathrm{D}$ in vitro tissues trapped on a microcavity chip. Lab Chip. 2008;8:879-884.

84. Huh D, Leslie DC, Matthews BD, Fraser JP, Jurek S, Hamilton GA, Thorneloe KS, McAlexander MA, Ingber DE. A human disease model of drug toxicity-induced pulmonary edema in a lung-on-achip microdevice. Sci Transl Med. 2012;4:159ra147.

85. Fattahi P, Yang G, Kim G, Abidian MR. A review of organic and inorganic biomaterials for neural interfaces. Adv Mater. 2014;26:18461885.

86. Hou C, Duan Y, Zhang Q, Wang H, Li Y. Bio-applicable and electroactive near-infrared laser-triggered self-healing hydrogels based on graphene networks. J Mater Chem. 2012;22:14991-14996.

87. Arndt S, Seebach J, Psathaki K, Galla HJ, Wegener J. Bioelectrical impedance assay to monitor changes in cell shape during apoptosis. Biosens Bioelectron. 2004;19:583-594.

88. Rothbauer M, Zirath H, Ertl P. Recent advances in microfluidic technologies for cell-to-cell interaction studies. Lab Chip. 2018;18:249-270.

89. Kim R, Nam Y. Electrochemical layer-by-layer approach to fabricate mechanically stable platinum black microelectrodes using a musselinspired polydopamine adhesive. J Neural Eng. 2015;12:026010.

90. Mohammadniaei M, Yoon J, Lee T, Bharate BG, Jo J, Lee D, Choi JW. Electrochemical biosensor composed of silver ion-mediated dsDNA on Au-encapsulated $\mathrm{Bi}_{2} \mathrm{Se}_{3}$ nanoparticles for the detection of $\mathrm{H}_{2} \mathrm{O}_{2}$ released from breast cancer cells. Small. 2018;14:e1703970. 